Annals of Warsaw University of Life Sciences - SGGW

Land Reclamation No 50 (3), 2018: 241-249

(Ann. Warsaw Univ. of Life Sci. - SGGW, Land Reclam. 50 (3), 2018)

\title{
Analysis of the yield of selected apple varieties in the first years after the planting the orchard
}

\author{
WERONIKA MASŁOWSKA, DANIEL LIBERACKI
}

Faculty of Environmental Engineering and Spatial Management, Poznań University of Life Sciences, Poland

\begin{abstract}
Analysis of the yield of selected apple varieties in the first years after the planting the orchard. The aim of the paperwork was to analyze the impact of innovative apple orchard cultivation on the yield of selected apple varietes: Galaval, Buckeye Gala, Golden Reinders, Grani and Fuji. The research ware conducted on orchard located in Gutowo Małe, Września county, in the Wielkopolskie province. The orchard was established in May 2016. The area of orchard is 4.0 ha and there are 7,600 annual and biennial apple seedlings. The analyzed apple varieties are used in foreign orchards. Cutting and forming trees is done in a different way, from the way it was done in traditional orchards. The purpose of this is to achieve better conditions of sunlight, which significantly affect the color of the fruit. Good coloring of fruit is one of the factors determining the profitability of crop. The aim of the study is to assess, the quality and quantity of yield of apple varieties, which have not been grown in Poland yet. The first harvest was recorded in 2017. The early cultivation period was characterized by the lack of irrigation. Atmospheric conditions of the studied area had a significant effect on the yield of apple trees. The considered year 2017 was defined as wet with a precipitation of $659 \mathrm{~mm}$ higher by $77 \mathrm{~mm}$ than the average over multiannual (2007-2017), while the temperature was higher by $0.4^{\circ} \mathrm{C}$ than the average over the period from 2007 to 2017. During the growing season, the sum of precipitation was $346 \mathrm{~mm}$ and slightly exceeded the long-term average. After the analysis of the harvest, it was found that the Fuji variety yielded best. Despite the dumping of more than half of the fruits from each tree, in order to improve their quality, the average yield was $15.0 \mathrm{t} \cdot \mathrm{ha}^{-1}$, in the first year of yielding.
\end{abstract}

Key words: fruit, precipitation, cultivation, construction, orchard

\section{INTRODUCTION}

Apples are one of the basic horticultural products, and Poland is an important producer in the World (Kierczyńska 2006). Therefore, the development of fruit production is rapid, especially in recent years (Kozaczyk et al. 2017). In the 2016/2017 season, apple production increased, mainly on the market in China and Chile. In 2017, the total fruit harvest from trees in Poland was between 2.6-2.8 million t, i.e. at the level of $30-35 \%$ lower than the production from the previous year (GUS 2017a, b). Apple yield amounted to only 2.5 million $\mathrm{t}$, which is a decrease of $30 \% \mathrm{com}$ pared to 2016.

The main purpose of fruit farms is to obtain higher and higher yields from a unit of area, as well as a quick return of incurred investment outlays, as soon as possible after planting (Pacholak 1986). New tools for sustainable production of fruit trees, taking into account climate change in particular, will be needed to achieve such effects (Tworkoski et al. 2016). 
As observed, the meteorological conditions have a special influence on the yields obtained. In Wielkopolska, precipitation deficits are recorded, which significantly reduce the possibility of intensification of production (Pacholak et al. 2005). At the same time, an increase in the average annual air temperature in Poland was observed, especially in the summer months (Skowera et al. 20014, Ziernicka-Wojtaszek 2016). In 2017, frost occurred in apple orchards during the flowering period. It caused large yield losses. Two spring frosts took place. The first in the second decade of April, and another in the end of the first decade of May. Such atmospheric conditions force the creation of the possibility of obtaining high yields with minimal expenditure (Rutkowski and Wojciech 2008). In order to prevent the yield reduction, the fruit farmers sought solutions used on foreign farms and tried to transfer them to Polish conditions. Innovative ways of constructing orchards are used, such as the prolongation of shoots for the development of the canopy in young orchards in order to best sunshine trees (Wünsche and Laska 2000). Effectiveness of new ways of cutting and forming trees is checked, the use of such elements as anti-hail netting and irrigation and fertilizing systems, as well as precisely selected sprays. However, their intensive use raises a lot of controversy in terms of environmental impact and health risks (Alavanja et al. 2004, Ma and Michailidies 2005, Chambers et al. 2014). On foreign farms, the use of natural enemies is tested to reduce pest populations as an alternative to insecticides (Cahenzli et al. 2017). These solutions are aimed at increasing yields, as well as protecting trees and fruits against diseases and adverse weather conditions. In modern fruit cultivation, rootstock for fruit trees are commonly used. The rootstock Washer control the size of trees are considered economically necessary for the apple orchards of high-density plantings, which are aimed at producing more fruit per hectare (Autio et al. 2000, Webster and Wertheim 2003, Tworkoski and Miller 2007). According to Reig et al. (2018), in modern production systems, the selection of a suitable rootstock is just as important for the profitability and success of new planting as the choice of a fruiting variety. Apple varieties previously encountered in the western regions of Europe, the United States and Australia are cultivated more and more often. In Poland, the most popular varieties of apple trees are: Cortland, Golden Delicious, Jonagold, Idared and Szampion. Growing apple trees in the climate of Poland is easy. Apple tree is a light-loving plant and relatively resistant to drought. However, according to Zhang's and Wang's (2017) research the degree of soil drying depends not only on the type of crop in the area, but also on the age of the orchard. Therefore, it is recommended to use an irrigation system to obtain a better yield. However, in Polish conditions, systems are made by growers to reduce costs, which leads to many design errors (Jeznach 2007). The resistance of apple to low temperatures, especially during flowering, depends on the variety. However, plants should be protected against frost. Apple has high soil requirements. The best conditions are fertile and humid soils with an alkaline reaction.

In the work, the varieties on which the research was conducted are: Galaval, Buckeye Gala, Golden Parsi, Gra- 
ny Chelenger and Fuji Heysi. These are, first of all, apple varieties used on foreign farms. The seedlings used are two-year-old trees. In this case, the problem of achieving satisfactory yield can be, as Fallahi (1984) writes, root system of young, newly planted plants, which exhibits relatively small possibilities of taking soil components. Therefore, it was important to determine the appropriate method and dose of fertilizer. However, one should remember about the increase in fertilizer costs and the growing awareness of the impact of pollution on the environment (Haynes and Goh 1980).

The aim of the work was to analyze the influence of the apple orchard method used in European Union countries on the yield of selected apple varieties, in the first years after the establishment of the orchard.

\section{MATERIAL AND METHODS}

The research was carried out in 2016 and 2017 in the apple orchard. The research object was located in Gutowo Małe, Września county, in the Wielkopolskie Voivodeship.

In the described region, up to a depth of $0.3 \mathrm{~m}$, there are sandy soils, and below there are boulder clays up to a depth of $47.0 \mathrm{~m}$. The object has an underground water intake from the depth of $119 \mathrm{~m}$. This underground water intake provides $50 \mathrm{~m}^{3} \cdot \mathrm{day}^{-1}$ of water during the growing season. The soil for planting has a $\mathrm{pH}$ level 6.6 for Unit 1 and 6.2 for Units 2 and 3.

Apple orchard, on which the research was carried out, was established in May
2016. Its area is 3.5 ha and is planted with 7,600 two-year-old seedlings. This area is divided into three units. Unit 1 has an area of 0.74 ha and was planted with 2,000 apple trees. In Unit 2 with an area of 1.04 ha, is located 2,750 seedlings. However, Unit 3, whose area is 1.09 ha, is planted with 2,850 apple trees.

The units were set out so that the trees grew at intervals of $1 \mathrm{~m}$, in rows every $4 \mathrm{~m}$. The basic structural element is the scaffolding supporting and stabilizing the trees, which are to reach a height of up to $4 \mathrm{~m}$. Between the trees there is a scaffolding consisting of pillars and steel ropes to support the anti-hail netting. When constructing the orchardňs structure, the first step consists in hammering every 12 trees of five-meter poles, one meter into the ground. Between these poles are placed another $4 \mathrm{~m}$ poles on concrete cubes. Then at the ends of the rows, so-called anchors are screwed into the ground to a depth of $1.5 \mathrm{~m}$. A steel rope is developed above the posts, which is attached to posts at the ends of rows. Then, from the end posts, steel rope stays are pulled into the previously screwed anchors. The posts on concrete cubes are needed for subsequent steel ropes that are also mounted across the orchard. Between the posts in the row there are horizontal wires at $60 \mathrm{~cm}$ to which the trees are tied (Fig. 1).

The trees are planted every $1 \mathrm{~m}$ in a row, and the distance between the rows is $4 \mathrm{~m}$. Trees are attached to wires, carried out horizontally between poles, using a biodegradation string (Fig. 2). Ultimately, apple trees are to reach a height of $4 \mathrm{~m}$. Therefore, in order to better il- 


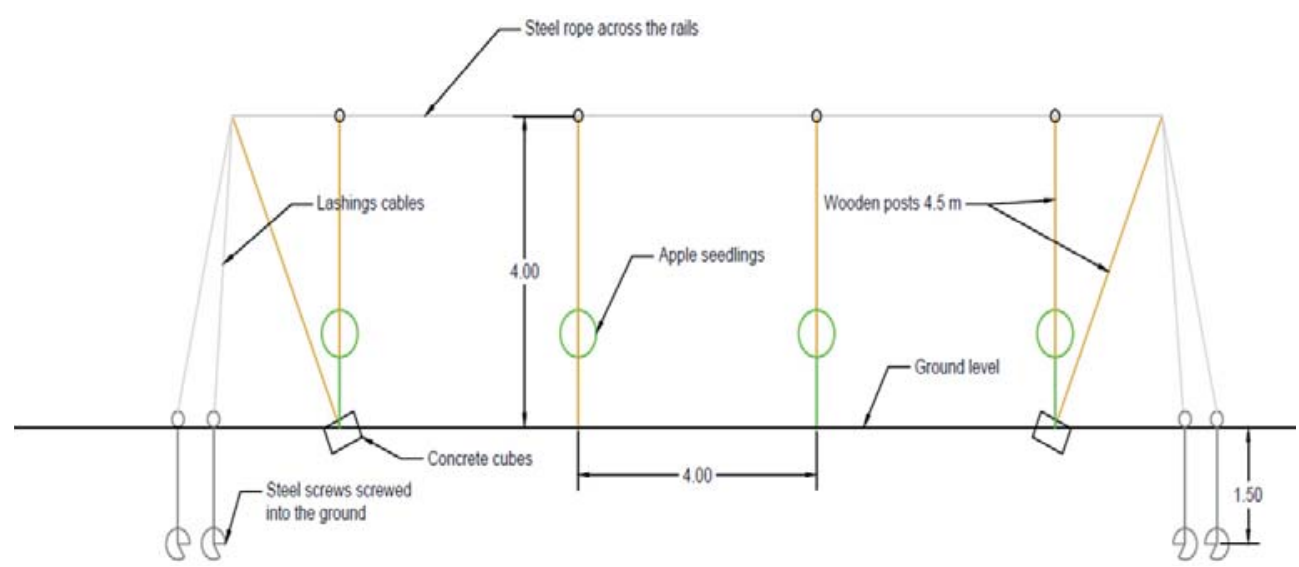

FIGURE 1. The construction scheme orchard - cross section

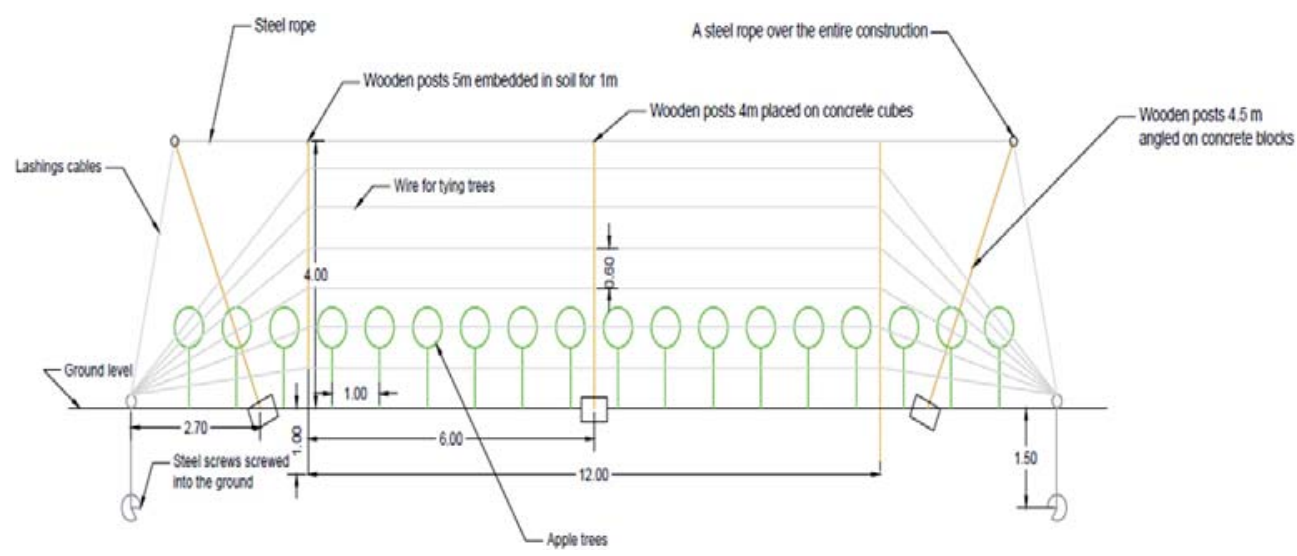

FIGURE 2. The construction scheme orchard - longitudinal section

luminate each fruit, the trees are formed into cones.

The following rules apply to the cutting procedure. The first rule is keeping only one trunk and removing all branches that are thicker from it. Competitive branches are cut, and those left behind, if necessary, are bent down with a string (Fig. 3). Branches are usually bent in the first years after planting and young branches.
The years 2016 and 2017 were the first since planting the orchard and at that time it was not irrigated. Therefore, the analysis of yield obtained from the discussed orchard can be made only on the basis of meteorological data.

The spraying was carried out from the moment the bud was broken to the end of the harvest, depending on precipitation. The period of the highest risk of scab appearance is April and May. 


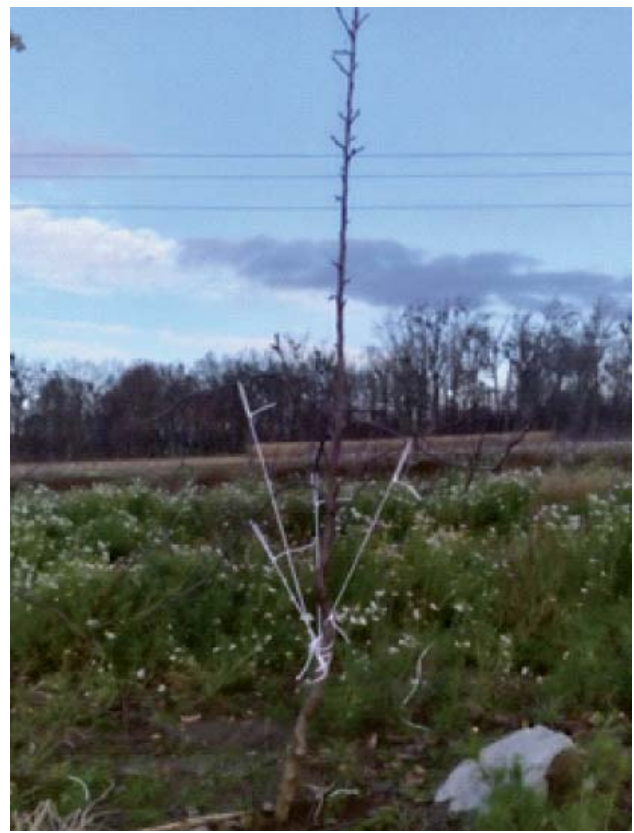

FIGURE 3. Forming a young tree by pulling the branches down (photo by Weronika Masłowska)

The spraying was carried out immediately after precipitation in the amount of $51 \cdot \mathrm{m}^{-2}$. The amount of precipitation was measured using a rain gauge located in the orchard. Pests against pests were performed on average every 10 days. Mixtures of Delan and Mospilan were used, at a dose of $0.5 \mathrm{~kg} \cdot \mathrm{ha}^{-1}$ dissolved in 4001 of water. The used sprayer was Tl 400s Orchard Sprayer.

The apple fertilization was done using Pulan. It was ammonium nitrate (ammonium nitrate $34 \mathrm{~N}$ ), $34 \%$ of total nitrogen, $17 \%$ of ammoniacal nitrogen, $17 \%$ of nitrate nitrogen. The fertilizer dose was $120 \mathrm{~kg} \cdot \mathrm{ha}^{-1}$. The fertilization dates were: $40 \%$ before the beginning of the growing season, $40 \%$ in the phase of flowering trees and $20 \%$ in the middle of the apple harvest period.

\section{RESULTS}

The study analyzed the multi-year 2007-2017 . The average temperature from this period was $9.8^{\circ} \mathrm{C}$, and the average precipitation was $582 \mathrm{~mm}$. The year 2015 was defined as a dry year with a precipitation of $425 \mathrm{~mm}$, and the wet year was 2010 with a precipitation of $723 \mathrm{~mm}$. In the analyzed years of 2016 and 2017, the average air temperature during the growing season did not differ significantly from the average temperature from many years (2007-2017).

In the 2007-2017, during the growing season, the temperature was $16^{\circ} \mathrm{C}$ (Table 1). The year 2016 was by $0.5^{\circ} \mathrm{C}$ warmer, and 2017 by $0.9^{\circ} \mathrm{C}$ cooler than the average temperature from multiyear in the growing season (Fig. 4). The average precipitation in the period from April to September for the analyzed multi-year was $365 \mathrm{~mm}$. In 2016, the precipitation was $29 \mathrm{~mm}$ lower, and in 2017 was $28 \mathrm{~mm}$ higher than the average for multi-year in the growing season (Fig. 5).

TABLE 1. Air temperature and precipitation during the experiment against the background of average values from multi-year (2007-2017) according to data obtained from the Poznań station

\begin{tabular}{|l|c|c|c|c|c|c|}
\hline \multirow{2}{*}{ Month } & \multicolumn{2}{|c|}{ Temperature $\left({ }^{\circ} \mathrm{C}\right)$} & \multicolumn{3}{|c|}{ Precipitation $(\mathrm{mm})$} \\
\cline { 2 - 7 } & $A V G$ & 2016 & 2017 & $A V G$ & 2016 & 2017 \\
\hline IV & 9.8 & 9.1 & 7.7 & 35 & 46 & 35 \\
\hline V & 14.5 & 16.0 & 14.2 & 56 & 34 & 34 \\
\hline VI & 17.8 & 19.1 & 18.0 & 69 & 82 & 63 \\
\hline VII & 19.9 & 19.5 & 18.4 & 103 & 128 & 128 \\
\hline VIII & 19.4 & 18.2 & 19.0 & 57 & 42 & 86 \\
\hline IX & 14.6 & 17.2 & 13.5 & 45 & 5 & 48 \\
\hline IV-IX & 16.0 & 16.5 & 15.1 & 365 & 337 & 394 \\
\hline
\end{tabular}




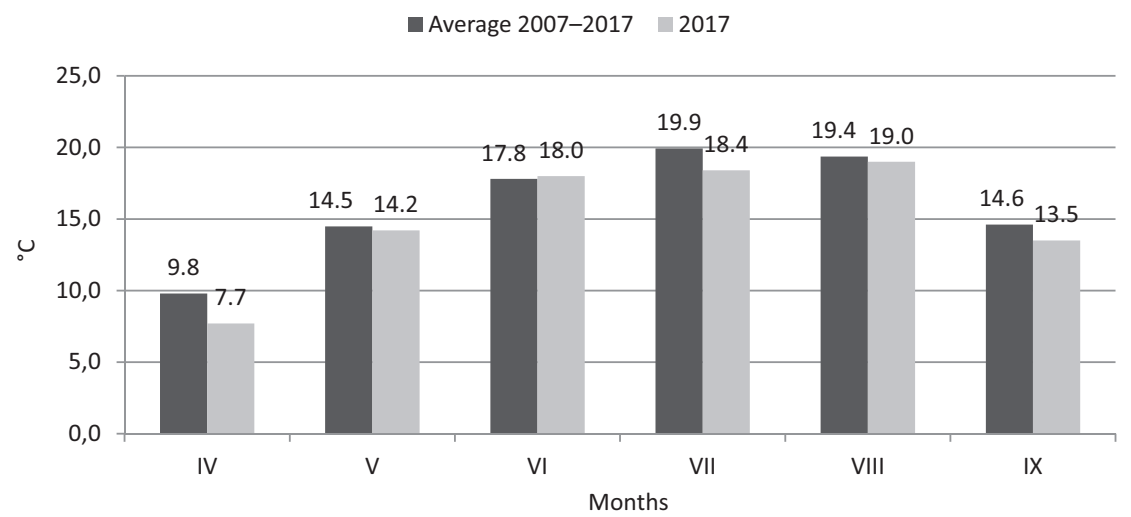

FIGURE 4. Monthly temperatures in the growing season of 2017 against the background of average monthly temperatures in the growing season from the years 2007-2017

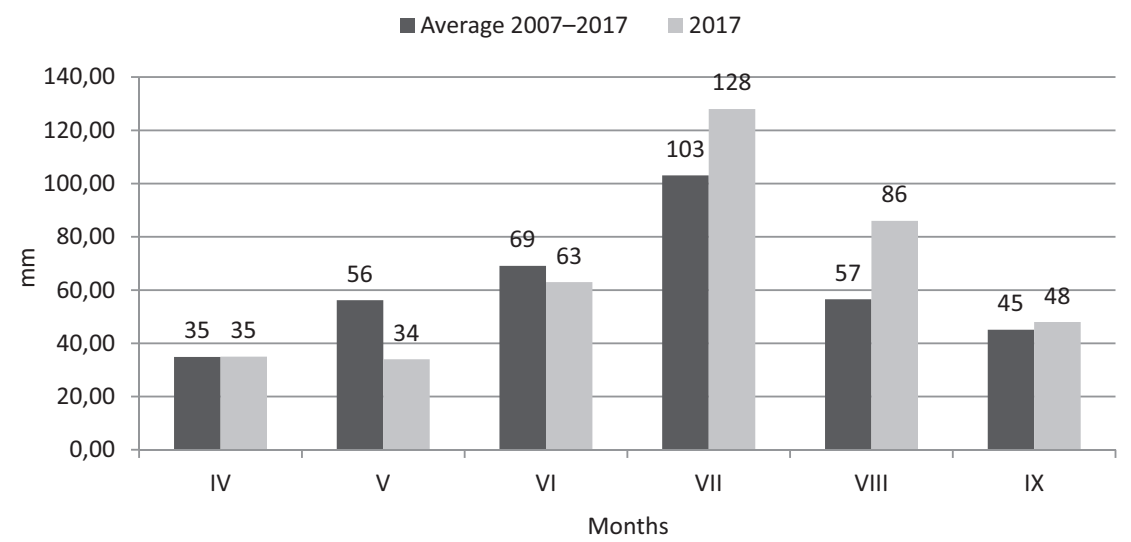

FIGURE 5. Monthly precipitation in the growing season of 2017 against the background of average monthly precipitation in the growing season from the years 2007-2017

The 2017 year is classified as wet with rainfall $77 \mathrm{~mm}$ higher than the average from multi-year. In the same year, during the flowering period of apple trees, there were frosts, which was the reason for the lower real yield in relation to the forecasted yield.

The analysis of the yield of selected apple varieties was carried out in the first year of fruiting trees, without the use of irrigation. The study was conducted on varieties: Galaval, Buckeye Gala, Golden Parsi, Grany Chelenger and Fuji Heysi.
The obtained data show that all varieties of apple trees yielded at a similar level (Fig. 6). The Golden Parsi variety constituted $24 \%$ of the harvest, and the $17 \%$ share of the harvest was Gala Bouckeye variety.

The average apple yield in meteorological conditions of 2017 for the orchard located near Września was about $15 \mathrm{t} \cdot \mathrm{ha}^{-1}$. The yield of $17.5 \mathrm{t} \cdot \mathrm{ha}^{-1}$, higher than average, gave Golden Parsi variety. The lowest yield equal to $12.5 \mathrm{t} \cdot \mathrm{ha}^{-1}$ gave Gala Bouckeye variety (Table 2). 


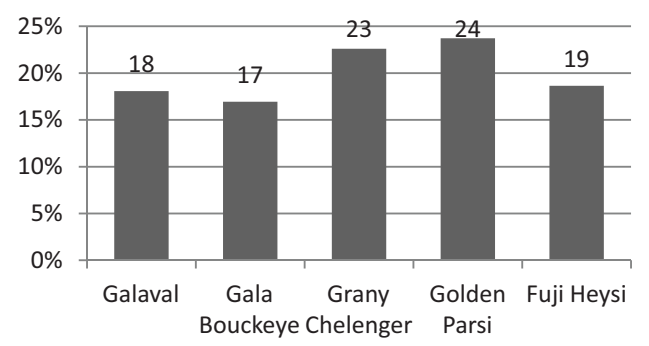

FIGURE 6. Percentage share of the apple varieties analyzed

TABLE 2. Apple yield of each variety in 2017

\begin{tabular}{|l|c|c|}
\hline Variety & $\begin{array}{c}\text { Number of } \\
\text { trees }\end{array}$ & $\begin{array}{c}\text { Yield } \\
\left(\mathrm{t} \cdot \mathrm{ha}^{-1}\right)\end{array}$ \\
\hline Galaval & 2450 & 13.3 \\
\hline Gala Bouckeye & 2450 & 12.5 \\
\hline Grany Chelenger & 250 & 16.7 \\
\hline Golden Parsi & 950 & 17.5 \\
\hline Fuji Heysi & 1500 & 13.8 \\
\hline
\end{tabular}

Also, the average weight of fruit harvested from one tree was at a similar level (Fig. 7). The largest fruit weight recorded for one tree was $7.0 \mathrm{~kg}$ and it was Golden Parsi variety. Whereas Gala Bouckeye variety gave the smallest weight of fruit from one tree in the amount of $5.0 \mathrm{~kg}$. The remaining vari- eties yielded at a similar level, respectively $6.7 \mathrm{~kg}$ - Grany Chelenger; $5.5 \mathrm{~kg}$ - Fuji Heysi; 5.3 kg Galaval.

\section{CONCLUSIONS}

1. In the first year of cultivation, it was important to use a fertilizer rich of phosphorus for better tree rooting. However, in the following years, the use of a fertilizer with a higher potassium content necessary for proper fruit growth, and in particular their level dyeing and firmness. The treatment of cutting trees, forming them in the shape of a cone, allows for better sun exposure of fruits and, as a consequence, their level of dyeing. To increase the yield, it was necessary to shed the fruit in the year of planting the trees and fruit cut in the period of fruit-setting.

2. Modern design solutions of the orchard allowed to obtain an average apple yield of $15 \mathrm{t} \cdot \mathrm{ha}^{-1}$ in the first year of fruiting.

3. The highest yield, amounting to $17.5 \mathrm{t} \cdot \mathrm{ha}^{-1}$, was recorded for the Golden Parsi variety. In contrast, the worst yielded Gala Bouckeye variety with the yield equal to $12.5 \mathrm{t} \cdot \mathrm{ha}^{-1}$.

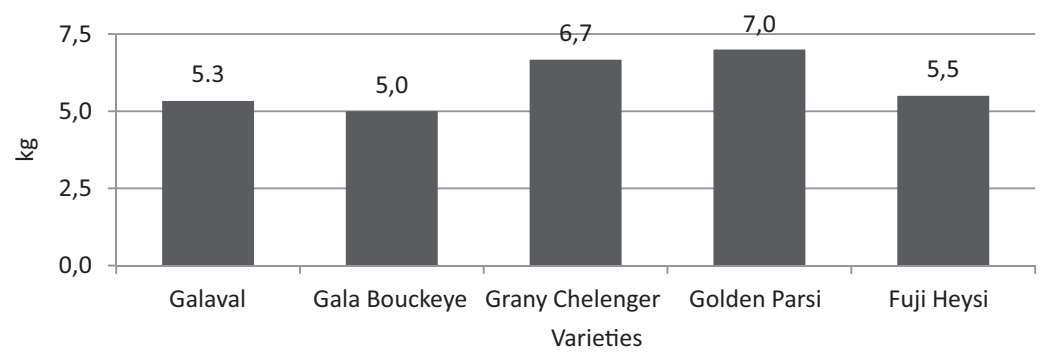

FIGURE 7. The average fruit weight of each apple variety for one tree 


\section{REFERENCES}

ALAVANJA M.C.R., HOPPIN J.A., KAMEL F. 2004: Health effects of chronic pesticide exposure: cancer and neurotoxicity. Annu. Rev. Public Health 25: 155-197.

AUTIO W.R., KRUPA J., CLEMENTS J. 2000: Performance of trees in the Massachusetts planting of the 1994 NC-140 apple rootstock trial over seven growing seasons. Fruit Notes 65: 1-3.

CAHENZLI F., PFIFFNER L., DANIEL C. 2017: Reduced crop damage by self-regulation of aphids in an ecologically enriched, insecticide-free apple orchard. Agron. Sustain Dev. 37, \#65. DOI 10.1007/s13593-017-0476-0

CHAMBERS J.E., GREIM H., KENDALL R.J., SEGNER H., SHARPE R.M., Van Der KRAAK G. 2014: Human and ecological risk assessment of a crop protection chemical: a case study with the azole fungicide epoxiconazole. Crit. Rev. Toxicol. 44: 176-210.

FALLAHI E., WESTWOOD M.N., RICHARDSON D.G., CHAPLIN M.H. 1984: Effects of rootstocks and $\mathrm{K}$ and $\mathrm{N}$ fertilizers on seasonal apple fruit mineral composition in a high density orchard. J. Plant Nutr. 7: 1179-1202.

GUS 2017a: Wstępny szacunek głównych ziemiopłodów rolnych i ogrodniczych w 2017 r. [Preliminary estimate of the main agricultural and horticultural crops in 2017]. Opracowanie sygnalne, Warszawa 28.07.2017.

GUS 2017b: Wynikowy szacunek głównych ziemiopłodów rolnych i ogrodniczych w 2017 r. [Preliminary estimate of the main agricultural and horticultural crops in 2017]. Opracowanie sygnalne, Warszawa 21.12.2017.

HAYNES R.J., GOH K.M. 1980: Distribution and budget of nutrients in a commercial apple orchard. Plant and Soil 56 (3): 445-457.

JEZNACH J. 2007: Some maintenance problems of the drip irrigation in Poland. Ann.
Warsaw Univ. Life Sci. - SGGW, Land Reclam. 38: 41-47.

KIERCZYŃSKA S. 2006: Produkcja jabłek w Polsce i perspektywy jej rozwoju po przystapieniu do Unii Europejskiej [Production of apples in Poland and prospects for its development after accession to the European Union]. Zeszyty Naukowe Szkoły Głównej Gospodarstwa Wiejskiego w Warszawie - Problemy Rolnictwa Światowego 15: 36-42.

KOZACZYK P., STACHOWSKI P., LIBERACKI D. 2017: Wpływ nawadniania podkoronowego na plonowanie jabłoni w warunkach sadu produkcyjnego [The influence of sub-crown irrigation on the yielding of apple trees under the conditions of the production orchard]. Infrastr. Ekol. Ter. Wiej. 1 (1): 33-40.

MA Z., MICHAILIDES T.J. 2005: Advances in understanding molecular mechanisms of fungicide resistance and molecular detection of resistant genotypes in phytopathogenic fungi. Crop Prot. 24: 853-863.

PACHOLAK E. 1986: Wpływ systemów sadzenia oraz nawadniania kroplowego na wzrost i plonowanie jabłoni [The impact of planting systems and drip irrigation on the growth and yielding of apple trees]. Poznańskie Towarzystwo Przyjaciół Nauk. Prace Komisji Nauk Rolniczych i Komisji Nauk Leśnych 61: 161-171.

PACHOLAK E., ZYDLIK Z., PRZYBYŁA C. 2005: Wpływ stanowiska oraz gospodarki wodnej glebyna plonowanie jabłoni odmiany Topaz [Influence of the position and water management of soil on the apple yield of the Topaz variety]. Rocz. AR Pozn. 365: 319-324.

REIG G., LORDAN J., FAZIO G., GRUSAK M.A., HOYING S., CHENG L., FRANCESCATTO P., ROBINSON T. 2018: Horticultural performance and elemental nutrient concentrations on 'Fuji' grafted on apple rootstocks under New York State climatic conditions. Sci. Hortic. 227: 22-37. 
RUTKOWSKI K., WOJCIECH J. 2008: Nakłady energetyczne na produkcję pomidora w szklarniach zblokowanych. [Energy expenditure on tomato production in block greenhouses]. Inż. Roln. 9 (107): 257-262.

SKOWERA B., KOPCIŃSKA J., KOPEĆ B. 2014: Changes in thermal and precipitation conditions in Poland in 1971-2010. Ann. Warsaw Univ. Life Sci. - SGGW, Land Reclam. 46 (2): 153-162.

TWORKOSKI T., FAZIO G., GLENN D.M. 2016: Apple rootstock resistance to drought. Sci. Hortic. 204: 70-78.

TWORKOSKI T., MILLER S. 2007: Rootstock effect on growth of apple scion with different growth habits. Sci. Hortic. 111: 335-343.

WEBSTER A.D., WERTHEIM S.J. 2003: Apple rootstocks. In: D.C. Ferree, I.J. Warrington (Eds.). Apples: Botany, Production and Uses. CAB International, Cambridge, MA: 91-124.

WÜNSCHE J.N., LASKO A.N. 2000: The relationship between leaf area and light Interception by spur and extension shoot leaves and Apple orchard productivity. HortScience 35 (7): 1202-1206.

ZHANG J., WANG L. 2018: The impact of land use on water loss and soil desiccation in the soil profile. Hydrogeol. J. 26 (1): 185-196.

ZIERNICKA-WOJTASZEK A. 2016: The frequency of occurrence of extreme and detrimental meteorological conditions for vegetation of crops in Poland (1971-2010). Ann. Warsaw Univ. Life Sci. SGGW, Land Reclam. 48 (2): 165-172.

Streszczenie: Analiza plonu wybranych odmian jabłoni w pierwszych latach po posadzeniu sadu. Celem pracy była analiza wpływu innowacyjnego sposobu prowadzenia sadu jabłoniowego na plon wybranych odmian jabłoni: Galaval, Buckeye Gala, Golden Reinders, Grani oraz Fuji. Obiekt badań jest zlokalizowany w województwie wielkopolskim, w gminie Września, w miejscowości Gutowo Małe. Sad założono w maju
2016 roku. Jego powierzchnia wynosi 4,0 ha i obsadzona jest 7600 rocznych oraz dwuletnich sadzonek. W sadzie uprawiane są jabłonie odmian wykorzystywanych w gospodarstwach zagranicznych. Zabieg cięcia i formowania drzew odbywa się w odmienny sposób niż stosowany dotychczas w sadownictwie tradycyjnym. Ma to na celu uzyskanie lepszych warunków nasłonecznienia, które znacząco wpływają na zabarwienie owoców. Dobre wybarwienie owoców jest jednym z czynników decydujących o opłacalności uprawy. Prowadzone badania mają na celu ocenę jakości i ilości plonu odmian jabłoni dotychczas niewykorzystywanych na terenie Polski. Pierwsze zbiory odnotowano w 2017 roku. Początkowy okres uprawy charakteryzował się brakiem nawodnienia. Istotny wpływ na plonowanie jabłoni miały warunki atmosferyczne panujące na badanym obszarze. Rozpatrywany rok 2017 określono jako mokry z opadem wynoszącym $659 \mathrm{~mm}$, będącym o $77 \mathrm{~mm}$ wyższym od średniej z wielolecia (2007-2017), oraz temperaturą wyższą o $0,4^{\circ} \mathrm{C}$ od średniej wieloletniej. W okresie wegetacyjnym suma opadów wynosząca $346 \mathrm{~mm}$ nieznacznie przekracza średnią wieloletnią. Po analizie odnotowanych zbiorów stwierdzono, że najlepiej plonowała odmiana Fuji. Mimo zrzucenia ponad połowy owoców z każdego drzewa w celu polepszenia ich jakości, uzyskano średni plon w wielkości $15,0 \mathrm{t} \cdot \mathrm{ha}^{-1} \mathrm{w}$ pierwszym roku plonowania.

Stowa kluczowe: owoc, opad, uprawa, konstrukcja, sad

\section{MS received 14.07.2018}

MS accepted 13.08.2018

\section{Authors' address:}

Weronika Masłowska

Instytut Melioracji, Kształtowania Środowiska

i Geodezji

Wydział Inżynierii Środowiska i Gospodarki

Przestrzennej

Uniwersytet Przyrodniczy w Poznaniu

ul. Piątkowska 94, 60-649 Poznań

Poland

e-mail: weronika.maslowska@up.poznan.pl 